\title{
Social and Psychological Implication of New Normal Adaptation
}

\author{
Self motivation, self understanding and self management task of \\ student expressions during learning on COVID 19 as \\ psychological changes to new normal life patterns
}

\author{
Rifa Hidayah ${ }^{1, *}$ Elfi Mu'awanah ${ }^{2}$
}

\author{
${ }^{1}$ UIN Maulana Malik Ibrahim, Malang, Indonesia \\ ${ }^{2}$ IAIN Tulungagung Indonesia. \\ ${ }^{*}$ Corresponding author. Email: rifa hidavah@psi.uin-malang.ac.id
}

\begin{abstract}
During the COVID 19 pandemic and efforts to adapt to the new normal are efforts to form a new culture in the teaching and learning process. Mastery of technology and psychological balance is needed in order to avoid all the pressures that arise during this pandemic. Efforts to strengthen mental spiritual psychology and physical endurance are of particular concern so that all new forms of activity can be carried out. Research based on data analysis framing student expressions that are revealed via Google form during a pandemic.
\end{abstract}

Keywords: leaning on line, new normal, a new lifestyle

\section{INTRODUCTION}

New patterns of life and social position, changes in economy, education are changing in an extraordinary way [1] with the presence of COVID 19 which has occurred almost all over the world and the condition of the transmission is so fast and has given rise to many victims. Mainstreaming of health is the main key in addition to maintaining and maintaining other aspects. Consistently, individuals with pre-existing pre-viral health anxiety can be vulnerable to this "vicious cycle", and increased viral anxiety in the context of an epidemic / pandemic [2] various efforts were made to prevent the expansion of the pandemic COVID 19 [3]. All can be said that they are seeking efforts to avoid a pandemic that has been going on for almost a year.

But all humans should live with all their thoughts, feelings, prayers, efforts to hope that this pandemic period will soon pass. However, this pandemic seems to be going on for a while, who knows how long, maybe half a year later and occurs in almost all countries. On the other hand, economic, education should also continu. Besides that, there is also an impact on all sectors, including in a way the psychological impact of the tourism sector in Tokiyo increases anger while economically decreasing income [4] COVID 19 also affects the teaching and learning process to be online with a choice of combined approaches between synconus and asynchronous with the choice of using online learning tools [5] be an adventure in itself for teacher-learners in the teaching and learning process.

Moreover, the learning process occurred due to an unexpected pandemic. Need E-proctoring is going to end up prevailing in online teaching [6] if needed during certain subject examinations. Human identity can reflect many sides of themselves and their environment [6] Therefore, to reveal how students are prepared, whether self-motivation can be built for learners who have received lessons during a pandemic. This study tries to analyze and reveal the cognitive conditions of affective learning and student behavior during a pandemic and whether they have become accustomed to the current new normal condition or not. 
The importance of excavation, of course, is to predict what the next lesson needs to be considered and prepared with the learners. This should be resolved because it is indeed an event to be faced and may change cultural patterns and different learning patterns. How can cognitive, affective and psychomotor strengthening be achieved by virtual face-to-face learning through online media. Research questions (1) Can digital media replace the face-to-face role of the teacher and become a mediator of knowledge between teachers and students? Research questions (2) Does the expression of the first learning experience of learning during a pandemic and through online media express the psychological elements needed to face the new normal?

\section{LITERATURE REVIEW}

During this pandemic, all parties have the authority to convey information to the public scientifically and provide accurate and fast information. How could it not be because the virus that is currently hitting, works and attacks humans very quickly? Including building cognitive scientific knowledge related to disease so that there is no mistake about the disease that is currently plaguing and psychological uncertainty where a person is faced with uncertain conditions as happened China [7]. This means that the psychological conditions of the community are very diverse. How to hold back all feelings and thoughts and predict uncertainty with the impact of this pandemic, including Indonesia, because the pandemic affects almost all countries in the world..

Far from the current conditions of uncertainty that hit mankind, but if in human psychology there is still motivation then someone will be able to face all the challenges that confront someone. Motivation is the strength of the self that is able to achieve what you want, both from one's intrinsic and extrinsic factors. Because it has motivation, someone will be able to complete tasks that should be completed on time [8]. As long as motivation resides in a person's soul, then someone will be able to find solutions to all the problems faced and achieve what someone wants. In a situation like this, the motivation appears whether it is not in the individual that can be seen from what someone does. Because from motivation, action will emerge as an indication of that motivation.

The motivation that needs to be built at this time is to achieve health status, quality of life, and academic achievement. as for quality of life is affected physical health, psychological state, level independence, social relationships, personal beliefs [9]. In Russia health is affected by a set of environmental, nutritional, and economic variables [10] in Indonesia too. Motivation to sustain the life of the Pandemic by pursuing a business model transformation with the support of digital technology [11] For teachers, lecturers and students, of course, the skills to apply technology are of minimum importance to be able to access their respective tasks, or if you want more skills, they can be used as a medium for business in the midst of a pandemic. However, when there are problems that arise, services are still needed, especially the increased stress during a pandemic students need mental health services[12] and very necessary.

Shouth Koea develop agglomeration skill-based indices for cognitive, social, technical, and physical skills [13] Where these skills are also needed for teachers and students, during this pandemic, the skills to care for personal health are also skills that all parties need to have. By itself the concept of teaching and learning is directed at the concept of independence so that students can improve their cognitive, social, technical, and problemsolving skills.

In online learning how to bring up social learning, whether through the FDGs' interactions can still be run, especially formal learning can stages behaviour modelling, role modelling and self-reflexivity [14] can be arranged in a virtual face-to-face meeting, so the teacher / lecturer gets a challenge how to screen lessons via on line. Even if the new normal in this pandemic period still lasts for one semester or will it still last a long time. Thus, in addition to learning during the pandemic, the teacher continues to try to teach students the skills and learning processes that are in accordance with the learning theories that have been used in face-to-face learning how to bridge it in virtual or online learning.

The learning scenario is not only limited to a certain age but also for all school ages because COVID 19 attacks all ages [15] so that all ages of all households fight and defend themselves to take care of their respective health to avoid getting affected. In the United States there is already a vaccine test [16] and adding to research research in the health sector and is always being tested in Korea [17] to the wider community, but requires psychological attitudes and readiness for new norml life changes. But the school continues.

Keep trying to find an understanding of each school's material regardless of the conditions with learning breakthroughs carried out in order to keep the education sector running as an impact of COVID 2019, such as including computer-based learning evaluations[18] in addition to the presentation of health restoration, care and prevention to all working age and school age and immigrants in Sanghai so as not to spread [19] establishing clinical learning through on line [20] when a pandemic is needed according to the needs of a pandemic and is directed at health care as in Pinzburg USA. 
In a pandemic era, building health strength, mental psychological strength towards all the impacts of COVID 19 is a concern, on the one hand, it remains to maximize the fulfillment of the needs for physical health on the other hand according to the conditions of each life's tarjet. Thus according to the teachings of the Quran that in any condition it is necessary to prepare physically mentally and spiritually in order to reduce the mental burden in the psychological. As is QS al Baqarah 247 About the strong physical capital is important to live life. Same thing with QS motivation to get something while still alive in the world QS al Qashash 77, QS Al Baqarah 53 about psychological strengthening through patience, endurance of suffering or usibah QS al Anbiya 83 and spiritual practice of prayer, fasting, tawaf in addition to physical work it strengthens mental endurance. Thus, during a pandemic, it is necessary to utilize all elements of the body, body, mind, feelings and self-optimization.

Figure 1. Framework of research

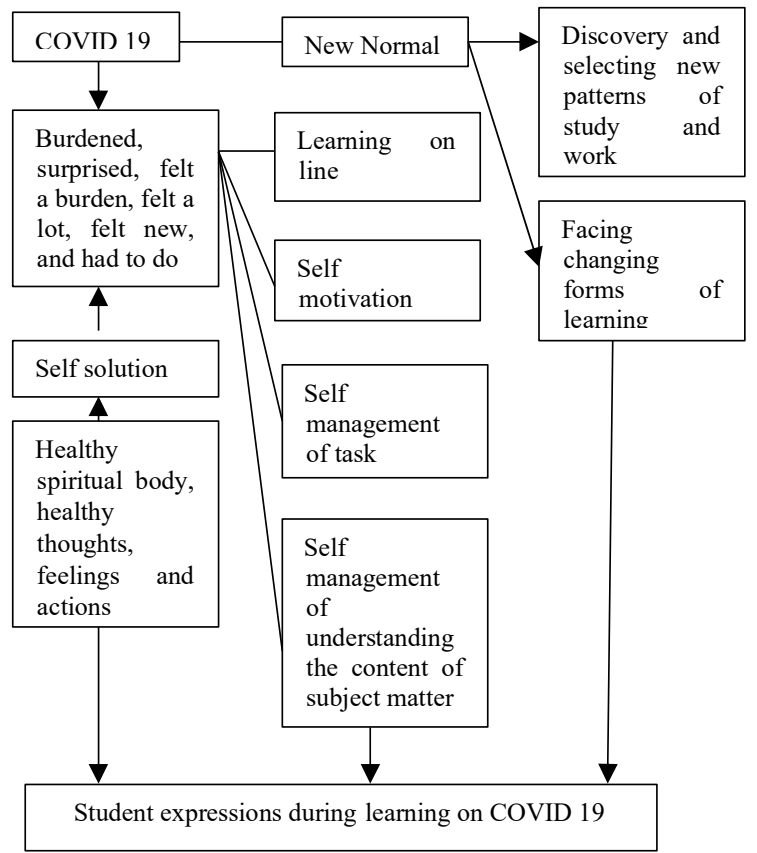

\section{METHOD}

This research is a qualitative research with a text analysis approach. Because it is taken from student responses regarding COVID 19 In learning there is basically a data analysis that examines the text in depth both regarding its content and meaning as well as its structure and discourse. Types of study texts Participant from 264 students from 3 group participant were taken as a sample of the words contained in a survey sample of 26 about how students thought about learning during a pandemic. What inner strength needs to be formed through the google form provided $10 \%$ of the content written and selected meets the criteria for expressions of toughness, problem solving, time management for task completion, maintaining physical stamina, self-motivation, finding new patterns of life or new normal that are revealed through participant's words.

Chart 1. First group participant

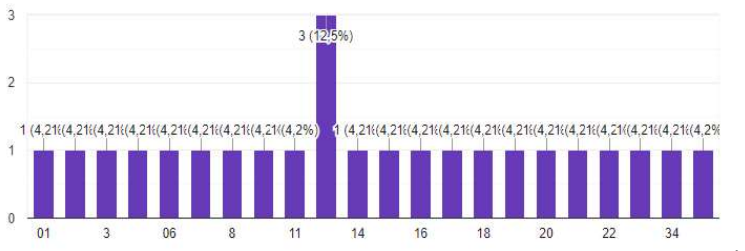

Chart 2. Second group participant

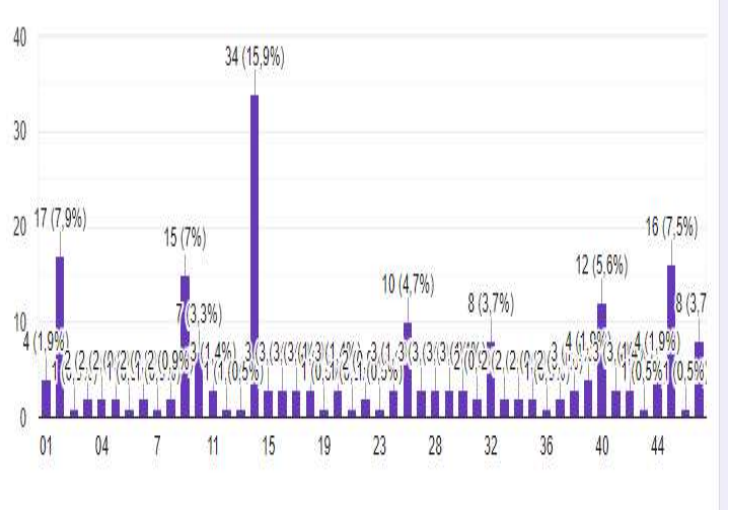

Chart 3. The third group prticipant

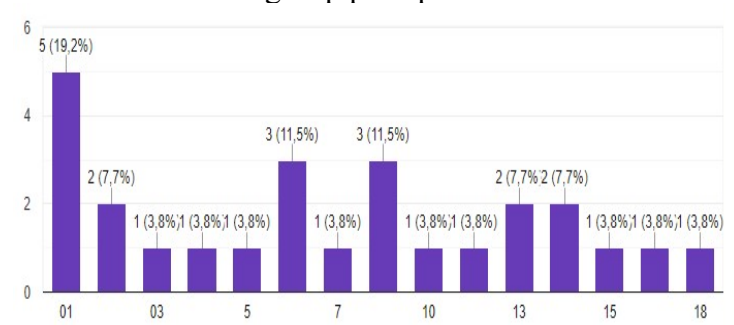

Data collection technique and analysis.

This is done by opening the link and giving it to students while participating in learning for one semester, starting from March 2020 to June 2020 through a form given to 3 class groups https://forms.gle/7s45V2MYiYGvFBd97. Data analysis was carried out by providing coding, selecting responses that meet the elements of self motivation, self understanding, and self management of tasks, then making conclusions. Then the data was be put into the Gason and Modigliani framing tools and sort out the things that meet the elements of frame devices, reasoning devices, met stages, roots, catchphrases, appeals to principle, exemplar and consequences. 


\section{Expressions data of student during learning:}

$\mathrm{NC} 2 \mathrm{~F}$ "The first way to learn during COVID 19, is to not stress in doing the tasks given during the adaptation period. If you experience difficulty or difficulty asking for help and working with friends. And the most important thing is to "have fun" in learning at home, so it's not too boring. Lessons that can be taken in learning during Covid-19 include mastering technology to support online learning. It will also create thoughts about more varied learning methods and models that have never been done. Then creativity will arise in developing the knowledge that is already owned. The existence of an online learning policy in addition to having the wisdom of improving the mastery of technological progress is that it can overcome the problems of the education process in Indonesia"

RIM2C" I learned by reading the materials that the lecturer had prepared. Sometimes I also watch teaching videos that I don't understand. If you feel less then I will look for other references available on the internet. Not only that, if I still don't understand, I will ask people who know more about the material such as seniors or almni. When a lecturer gives me an assignment and I feel lazy, I will motivate myself to study harder for the hope that my parents have entrusted to me. The lesson we can take from learning during the COVID 19 pandemic is to provide a teaching on the meaning of patience and struggle. Why is that? Because when this pandemic is occurring, it will directly interfere with teaching and learning activities which cause students or students to have more opportunities not to attend lessons and cause more laziness. Therefore, let's fight together against the present and prepare for the future carefully".

OMP2C" In the current condition amidst the COVID-19 / Corona pandemic. I study online by using the WhatsApp, classroom, and Telegram and Edmodo applications as well as email. With these 5 applications, it helps me learn. However, there were many things that I felt when learning online for the first time. I had difficulty understanding the material presented because I am an audio-visual type of learning, so if it is only in writing and a little explanation, I really understand the material presented. The lesson that I can take from the current situation is that we have to be even more enthusiastic in learning. We must not make this pandemic an excuse to slack off. From my personal point of view, I am very grateful because my condition is more fortunate than other friends, for example, whose house has no signal. In fact, there are still many children out there who don't have the income to study. So, we who are given the convenience should be more enthusiastic in learning and reduce complaining and always be grateful. Hopefully this pandemic will end soon".

HM2C' The way I do learning at home is by using Android, online system learning can be done using the WhatsApp application, telegram, google classroom and others. By using this online learning system, sometimes there are various problems faced by students and teachers, such as subject matter that has not been completed by the teacher and then the teacher replaces with other assignments. This is a complaint for students because the assignment given by the teacher is more. Behind these problems and complaints, it turns out that there are also various lessons for education in Indonesia. Among them, students and teachers can master technology to support this online learning. In this era of increasingly sophisticated technological disruption, teachers and students are required to have abilities in the field of learning technology. Mastery of students and teachers of learning technology is very varied, a challenge for them. With the Work From Home policy, it is able to force and accelerate them to master digital learning technology as a necessity for them. The demands of these needs enable them to find online media that can support as a substitute for direct learning in class, without reducing the quality of the learning material.

IRA2C "When the corona virus pandemic began in Indonesia, the education system was implemented from home only. This is what makes the implementation of online / online lectures. Indeed, at the beginning of this system there were no obstacles, but over time this online lecture became a burden for students, especially students who had just received education in college. At first students did not mind the existence of an online system that did not require students to go to campus with unpredictable weather, it could even be done casually, for example by lying down, eating, drinking, etc. However, over time lectures on the online system have had many negative effects. Besides consuming a lot of time and quotas, there are some lecturers who only give assignments without any explanation. In addition, students are required to stare at gadgets for a long time, causing eye pain. So, like it or not, students have to make more sacrifices in this system. Basically, this system is arguably quite effective in its implementation. However, lecturers are expected to carry out their duties properly and also need proper time management so that it does not take too much time and students don't stare at gadgets for too long".

HM2C" The way I do learning at home is by using Android, online system learning can be done using the WhatsApp application, telegram, google classroom and others. By using this online learning system, sometimes various problems faced by students and teachers arise, such as subject matter that has not been completed by the teacher and then the teacher replaces it with other assignments. This is a complaint for students because the assignment given by the teacher is more. Behind these problems and complaints, it turns out that there are also various lessons for education in Indonesia. Among them, students and teachers can master technology to support this online learning. In this era of increasingly sophisticated technological disruption, teachers and students are required to have abilities in the field of learning technology. Mastery of students and teachers of learning technology is very varied a challenge for them. With the Work From Home policy, it is able to force and accelerate them to master digital learning technology as a necessity for them. The demands of these needs enable them to find out which online media can support as a substitute for direct learning in class, without reducing the quality of the learning material "

VEL2C "The way I learn in the midst of this corona virus is that I listen to online presentations and videos from my friends, listen to explanations from lecturers through online learning media starting from google classroom, WhatsApp, telegram, edmodoo, etc. In addition, it is not uncommon for lecturers to assign assignments in each of the media used. With that assignment, I had to study on my own, analyze myself, and do the task myself. The lessons that can be taken from this online learning are practicing patience with internet connection and internet quota, practicing honesty by doing assignments independently, being able to do double roles at home, namely learning and helping parents, hone reading and listening skills, and saving (energy, time) and costs) to study. Hopefully this virus will end soon and everything will return to normal."

$N Q A 2 C$ "Lectures conducted online are not optimal because there are some mentors who rarely and almost never accompany the discussion. From there we also feel the lack of material explanation from the supervisor. We cannot receive a course perfectly if only burdened with so many tasks without any discussion and explanation from the supervisor"

AH2C "Indeed, at the moment the impact of COVID 19 is changing the learning process by learning online or distance online, that I myself also do online learning with various types of online, such as learning most often via wa, with discussions and presentations. Questions and answers can be done, there is also via google classroom which can be via audio, there is also a presentation using the edmodo app using Vidio for presentations. All of that is my way of learning online, which must be able to adjust to sudden schedules and be active or continue online. Moreover, there is also only by completing tasks, so you must be able to manage the time so that it is done quickly. For the wisdom of online learning itself, that is, we can master technology that supports online learning, that many of which I didn't know at first became aware that by studying at home there can also be time for family, such as the morning before there is a lecture, it can help mothers or even can I have time to play with my younger siblings. I think online learning is quite fun as long as we can stay focused, active, in online learning like this", 
EFZ2D "We have trained how to study at home so far to be independent and disciplined. Learning is done from home with an online learning system for students or university students, this is an activity that requires adaptation for them. This online learning is one way in the presence of this pandemic. We as students or students must comply with what the government recommends with this online learning, this can also break the rope of spreading covid-19. During learning at home we always update about assignments because if we don't update we are afraid of missing the lesson. Online or online learning is usually like via watsapp, google classroom and others. And in my opinion this way of learning is less effective and is usually also constrained by signals as well, it is better to learn face-to-face than online or online. Online learning is distance learning that uses computers or gadgets, where teachers and students communicate interactively using communication and information media. Online learning is very helpful for education during this pandemic, this online can improve skills by using various online learning applications.

"IC2D" With the Covid-19 Pandemic all activities must be carried out from home. Now and right now, lectures are already using the online lecture system or can be called online. Usually my class uses online learning using google class media, telegram, classroom, to edmodo. However, the most frequently used one is via WhatsApp. We can conduct online lecture activities just like regular lectures offline, namely with presentations from each group, after which there is a question and answer session, there is a session to argue or add an audience the answers of the presenters who are considered still lacking. There are also those who hold lectures from lecturers for all students or female students, or there are even lecturers who give some assignments to be done by students and female students. online, the wisdom that we can learn is the lecture system is not only done offline. However, even when online, lecture learning activities can also run. Students with teachers and students with lecturers can use these technology tools to support online learning. So, all of us can make useful use of technological tools in this modern era."

AZ2D "The learning process that I did during this pandemic was the same as the others, namely doing it through social media or doing it online, assignments from the lecturers were given and I did and collected through online too. There were negative and positive impacts during this online learning period, the positive impact I got from this online learning was that it made me more independent and creative in doing assignments, which originally had many tasks given in groups, then in this situation flow is done independently, it can sharpen my brain to think more critically. Whereas the negative impact of online learning is the difficulty of getting good and fast signals, sometimes there are network disturbances that make the material being presented or presented is left behind, learning is less effective, because usually those who often get material clearly in class, now have to understand it themselves without there is a brief "advance explanation.

SAC2D "Lessons we can take $\sim$ Lessons that can be taken during learning in the midst of the Covid-19 pandemic, namely better mastering technology when learning online. Regarding the google classrom application, edmodo and so on. In addition, I have more courage to make videos about presentation materials online, so that the delivery of the material is easier to understand. Furthermore, at the time of learning at home parents can supervise directly. The use of social media will be more useful, because it emphasizes the need for learning and has a more positive impact on gadget users. On the other hand, online learning can be done more casually, but assignments remain a separate responsibility for students. In my opinion, studying in this pandemic situation is less effective. I find it difficult to find material because I can only find material from e-books or journals on the internet. E-books are also not as complete as books in libraries and incomplete pages. The signal is sometimes lost, the cellphone becomes sluggish, and the eyes are sore from seeing the cellphone too often. But that is the way I learn during this pandemic. Rely on Mobile. The lesson I can take from this situation is that I know what it feels like to study without having to go to campus. Create video assignments or presentations. Learn through google classroom, telegram, whatsapp, email, and google form. Closer to family, missing relatives, college friends, as well as a room. And because of this pandemic I feel that I really have to appreciate learning on campus. Active in learning, not just coming and being absent. Thank you."

ZN2D In a situation like this when the covid-19 virus is present and this virus is very easy to spread, learning is held at home the things I do when studying at home is to be good at dividing time when situations like this don't collide with other schedules, and if there is a task, try not to procrastinate so that the task does not get pile up so that it does not get completed, instead it increases in number. And have to be disciplined in time in terms of learning, don't waste time with things that are of no benefit. study according to the specified schedule and usually there is also a schedule that can be forward or postponed and sometimes the schedule can be sudden. Then then learn through the whatsapp application. This method is the most effective and easy because there is already a WhatsApp group that is in accordance with the course, so you directly monitor the group and also directly discuss and answer questions in the group. The next learning is through Google Classroom, which is an existing application on Google specifically for learning like in class by being able to discuss sending text or material that you want to discuss. And maybe that's my way of studying at home and in this covid-19 state. The lesson that we can take in this event is that we are being tested by patience and we should be more grateful for the existing situation, value more time and believe that something like this must have a silver lining. The lesson is we can learn from all events like this and God willing, we can live it and we must believe that behind all this Allah planned something invaluable for all of us. Aamiin "

HT2DA "as a result of the Covid-19 pandemic, various policies have been implemented to cut the spread of the Covid-19 virus in Indonesia. One of the efforts made by the Indonesian government is implementing physical distancing or what we often call an appeal to maintain distance between people. This effort from the government is aimed at the Indonesian people so that they can break the chain of spreading the Covid-19 pandemic. Education in Indonesia is also one of the areas affected by the Covid-19 pandemic. Due to restrictions on human interaction, the teaching and learning activities in Indonesia will be closed. To replace teaching and learning activities in schools, learning from home is carried out using an online system. From the use of this online learning system there are a few obstacles, such as problems in the signal. Maybe at the time the signal presentation was not supportive, in the end the presentation was not smooth because We can take a lesson from the Covid-19 pandemic, namely that we as ordinary humans must still remember Allah, do not forget to always ask for and ask for protection, and do not forget to continue to "live healthy and maintain health"

MR2D One way to learn during the Covid -19 pandemic is by learning online or online. The things that I can apply in online learning are first, managing the study time, which during this pandemic period coincides with the fasting of Ramadan. Online classes while fasting are still running, so I have to be able to manage time between online lectures and other activities. To be more precise, I made a schedule that I will work on that day. With a schedule I can allocate time accurately. Second, do not delay work, apart from online lectures there are additional assignments that must be completed. Usually I do additional tasks after finishing tarawih prayer because after finishing tarawih prayer my mind can focus on the task to be completed. Third, the appropriate way to learn, to avoid the drowsiness or laziness that attacks me, occasionally listening to music or other things that can make us entertained. By relaxing and relaxing learning becomes more effective. The lessons that can be taken during a pandemic are the closeness and intimacy of the family that is getting closer, the awareness and cleanliness of the community is getting better with the birth of awareness of washing hands and implementing a healthy lifestyle, the growth of social solidarity in society. The existence of a government policy to conduct distance learning via online can provide benefits, namely to increase awareness of mastering current technological 
advances. With this plague, it reminds us to always get closer to the creator, Allah SWT. Hopefully this epidemic will soon pass and we can all carry out activities as before"

FT2D "There are so many lessons that can be learned from the pandemic, including: students become more familiar with and literate in technology better than before. All learning carried out online makes students inevitably update the latest communication technology students can use their spare time by honing non-academic skills at home such as business, online lectures, development in their mobile devices, students can study while hanging out with their families at home, because students who come from outside the city usually rarely return home; students become independent by preparing new learning patterns during this pandemic, learning becomes so easy because with the role of technological sophistication, students are increasingly able to make the habit of health and safety protocols during a pandemic; students are able to implement a more healthy life by washing hands, not touching, using masks and other health protocols. students are able to find various book references or learning materials as easily as clicking the internet; Besides that, the lesson of this corona is that students are able to focus on learning with a learning pattern system that is set by themselves at home"

MR2D One way to learn during the Covid -19 pandemic is by learning online or online. The things that I can apply in online learning are first, managing the study time, which during this pandemic period coincides with the fasting of Ramadan. Online classes while fasting are still running, so I have to be able to manage time between online lectures and other activities. To be more precise, I made a schedule that I will work on that day. With a schedule I can allocate time accurately. Second, do not delay work, apart from online lectures there are additional assignments that must be completed. Usually I do additional tasks after finishing tarawih prayer because after finishing tarawih prayer my mind can focus on the task to be completed. Third, the appropriate way to learn, to avoid the drowsiness or laziness that attacks me, occasionally listening to music or other things that can make us entertained. By relaxing and relaxing learning becomes more effective. The lessons that can be taken during a pandemic are the closeness and intimacy of the family that is getting closer, the awareness and cleanliness of the community is getting better with the birth of awareness of washing hands and implementing a healthy lifestyle, the growth of social solidarity in society. The existence of a government policy to conduct distance learning via online can provide benefits, namely to increase awareness of mastering current technological advances. With this plague, it reminds us to always get closer to the creator, Allah SWT. Hopefully this epidemic will soon pass and we can all carry out activities as before"

FT2D "There are so many lessons that can be learned from the pandemic, including: students become more familiar with and literate in technology better than before. All learning carried out online makes students inevitably update the latest communication technology; students can use their spare time by honing non-academic skills at home such as business, online lectures, development in their mobile devices; students can study while hanging out with their families at home, because students who come from outside the city usually rarely return home; students become independent by preparing new learning patterns during this pandemic, learning becomes so easy because with the role of technological sophistication, students are increasingly able to make the habit of health and safety protocols during a pandemic; students are able to implement a more healthy life by washing hands, not touching using masks and other health protocols. students are able to find various book references or learning materials as easily as clicking the internet; Besides that, the lesson of this corona is that students are able to focus on learning with a learning pattern system that is set by themselves at home "..

$B B 2 D$ "In my opinion, lessons from COVID 19 are: 1. We can arrange a study schedule at the right time so that the material being studied is quickly understood well. 2. We can learn calmly and can concentrate more. 3. Cellphones, which are usually used for a lot of telephones or chatting, are now more often used to access websites or platforms that are used. Communication with friends can be done almost every day to discuss the task at hand. 5. For overseas children, they can spend time with their families at home. 6. Parents can better supervise their children. 7. through online learning, it can provide us with the benefit of increasing awareness to master current technological advances. 8. Parents can better supervise their children in learning. 9. We prefer to maintain cleanliness by washing our hands frequently and using masks when. out of the house. 10. We can also exercise frequently to keep the body healthy. We can be closer to parents"

KHPSI Covid has many positive and negative impacts, both for students and lecturers, but what I will convey is my experience during the pandemic regarding my learning method. Honestly, the way I learn at this time is really out of the ordinary, yesterday it could be a group and somewhere but now we have to be alone and in our own place too, yesterday we could meet face to face and share direct thoughts but now we are made to do something ourselves and make use of it. existing technology. The lesson I got from this pandemic. I am more free to learn and hone my own skills and of course I am helped by existing technology. With information technology now I am able to learn and do it well without having to think about playing or hanging out where the results are not what we expected. With that, I personally feel tremendous wisdom from this pandemic, one of which is from studying at home close to my family and being able to increase closeness in my family. My prayers are that this pandemic will pass quickly so that we can meet and learn together to tell our own stories during a pandemic "

FKPSI "Arranging the time of study where the pandemic and fasting period, online lectures and assignments seem to pile up so it is necessary to take appropriate steps to regulate productive hours so that they are not wasted into passive time and the most effective time for learning is after the lowest where the mind has started to improve and can be functioned. to do good. Determining the priority scale so as to complete the task optimally and not burdensome, determine the priority scale of the given task), Do not delay work (if you delay work, the work will accumulate and make yourself lazy), Must think positively (many tasks with narrow deadlines often considered a terrible scourge, get rid of these assumptions and start to make friends, interspersed with entertainment (when saturated with terrible tasks, alternating with listening to music, verses of the Qur'an or others that can entertain us. The lessons that can be taken are tasks are automatically completed optimally, on time, motivates us to be more enthusiastic about learning and doing activities so that it can calm the mind and eliminate fatigue.

ESPSI "The world of education in Indonesia is currently being shocked by the COVID 19 outbreak and many have been exposed to this irus, including in Tulungagung. As a result, the government issued policies that must be obeved in order to break the chain of the spread of COVID 19, considering that education is also one of the areas affected. Therefore the ministry of education issued a policy to replace teaching and learning activities using the online system. In my opinion, this online system has many shortcomings, but on the other hand there are lessons such as being able to master technology that supports online learning, so we can find online media that we can use as a substitute for learning in class without reducing material. The next lesson is that we become wiser in using cellphones, if previously we used cellphones just for fun, now we can use them for useful things such as college assignments and our time at home with family becomes very much. The way I learned during the Coid 19 pandemic was by managing time "

MZLS2 "Covid-19 or what is often called the corona virus which is currently endemic in Indonesia has claimed many victims because of it. The virus that was brought by other countries that spread in Indonesia is very much feared by the public even throughout the world. Because of this, in order to decide the spread of the corona virus, the government recommends that all its citizens stay at home to break the chain of spread. From here, administrators of every campus throughout 
Indonesia give all students a full day off in order to avoid large crowds to break the chain of the spread of Covid-19. With that all lectures are systemized online and all assignments are transferred online. maybe for some students this is the beginning of suffering, because all lectures are online and the assignments come and go non-stop. Learning during the Covid-19 pandemic is very hard for some students. Not because of anything, but because some students do not understand if this lecture learning is done online, not all students understand the explanation of the WA group lecturers, so many students are confused about the assignment given. And in my opinion, online lectures are less effective, because one of the lecturers uses an application that confuses the students and even makes it very difficult for students because of the assignments that keep coming without providing any material about the course. So this is what makes the students confused themselves. However, if the positive side is taken, from here for students who are less active and underestimate their assignments, this is where the lazy souls of students will rise up and will be diligent in doing assignments seriously and will continue to pay attention to online lectures well. well, especially besides being a student I am also a teacher so I have to be able to divide my time well. To do my college assignments, I usually make my own schedule so that my assignments can be completed on time. If there is material that I do not understand or have not mastered I usually googling to find journals about the material and I read not just one reference but several references, if the material I don't understand is not found on Google I usually ask a friend who smarter than me. Due to situations like this our laziness level increases, therefore motivating ourselves to often learn is also very necessary for our own good and progress..

RIS2 The learning process is so different that I inevitably have to adjust to a new learning method, namely the online system. Where learning is done online and using several applications on HP. This method of learning can be through the whaatsapp application, zoom application, google classroom, etc. With a learning system like this, $i$ makes me find it difficult to accept the material presented by the teacher or lecturer. The limitations of the media used and the uncertainty of network disruptions make this learning system less effective. To balance this, the way I can do is to read a lot of material that has been given by the teacher or lecturer. By adding to the literature that will help me add knowledge. If there is material that I still don't understand, I usually ask the lecturer right away or search for information via google. From this pandemic there are many lessons or lessons that we can take. For example, with the Covid-19 pandemic, we can spend more time at home and spend time with family and have plenty of time to rest at home. In addition, the existence of an online learning system will make students more creative and active in looking for learning resources. During a pandemic we have plenty of time to develop our hobbies. With this virus, we are also diligent in maintaining cleanliness and health, from diligently washing our hands and using masks when traveling. In addition, there are other lessons that we can take, namely that with the Covid-19 pandemic, we are more efficient in managing finances. This is because we, who used to go shopping at the mall, go to a restaurant or just have a coffee in a café, now don't go out anymore, because to go to these places, we have to think twice about the dangers of gathering with people. Because we don't know whether other people are exposed to the corona virus or not $"$

RR2S The COVID 19 pandemic that has hit the world including Indonesia has disrupted all economic, social and even educational activities. Because, with a pandemic, the government must take policies to break the chain of spreading the virus. Implementing a psychological distancing policy requires me to study from home (online). Learning from home was very difficult for me at first. Because when studying at home using artic online requires a stable internet network. However, at my home the internet network is very difficult so I have to go to a certain place where there is a network. Behind all that, of course there is a silver lining. The lesson that I get from online learning is that I love reading because the art used is not through the meaning of call but by using google clashroom. Besides that, it was so cost-effective that at first I had to spend gas money to go to campus. Besides that, with the learning at home, I spend more of my time with my family and at home, this month's fast is a moment to get closer to ALLOH SWT."

ANS2 "Since covid-19 has become a worldwide pandemic, all activities outside the home including lectures must be carried out at home. In order for lectures to continue according to the syllabi, the learning activities in this semester's lectures are carried out online, namely through online forums in google classroom. Through this online forum, the discussion about the material in this child education psychology course can run well. Even though the lectures are held in their respective homes, they are more relaxed, but not carelessly doing assignments or discussions in forums. The way I studied at home during this pandemic started with timing studies. Besides being in accordance with the lecture schedule, I also arrange a study schedule outside of class hours to do assignments or add reading material. Studying at home makes me more relaxed because I can choose a comfortable place to study. To find assignment references, I searched and read journal articles on the internet. Besides that, during lecture discussions I also write important notes. Although the Covid-19 pandemic has reduced the space for activities outside the home and has had an impact on various aspects of human life, there are many lessons that can be taken from the existence of this pandemic. Some of the lessons I have felt as a result of this covid-19 pandemic, including the covid-19 pandemic, is not a disaster, but a warning from Allah SWT for mankind to strengthen faith. So, while at home it is hoped that it can further increase devotion and also kekusyu'an in worship. In addition, our sense of humanity is also tested to be able to care for each other by helping people who are in distress due to the impact of the Covid-19 pandemic. Then, the closeness to family members is also getting tighter, than before the time for the family was spent doing activities outside the home. Lifestyles are also getting better because we must always keep ourselves and the environment clean and increase immunity by exercising and eating healthy foods. I am sure this pandemic will end quickly if we comply with the rules according to the health protocol from the government".

NAPSI Lectures during the current pandemic, namely the Covid 19 period brought many changes in the teaching and learning process, which of course required lecturers and students to adapt to new and different circumstances. Where we have to stay at home to stop the chain of transmission of the COVID 19 virus. On the other hand, learning must continue so that courses are not left behind. Then there are new innovations in the teaching and learning process. The way that is actualized on campus is by using artic online / online. Where lecturers and students also use social media, such as WA Group, Telegram, Edmodo, Telegram, etc. With social media, online lectures can be carried out. Although of course there are many shortcomings / obstacles that are felt by lecturers and students, such as lecturers who cannot directly monitor student attendance, because many just list attendance but do not take online lectures to completion. Another obstacle is the signal, especially the students whose houses are located in areas with little network, which hinders them from learning. Next is the difficulty of coordination during group assignments, because members cannot meet face to face, so it is more difficult to discuss assignments, complete them, even when presenting them. And there are many other obstacles. Even though there are many difficulties in the online lecture process, at least learning can continue and bring benefits to lecturers and students 
Table 1. The expression virtual face-to-face sometimes replaces ordinary face-to-face

\begin{tabular}{|c|c|c|c|c|}
\hline Participant & $\begin{array}{l}\text { Virtual } \\
\text { gaze } \\
\text { replaces } \\
\text { teacher }\end{array}$ & $\begin{array}{l}\text { Virtual } \\
\text { gaze } \\
\text { cannot } \\
\text { replace } \\
\text { teachers }\end{array}$ & $\begin{array}{l}\text { Understand } \\
\text { the } \\
\text { material }\end{array}$ & $\begin{array}{l}\text { Do not } \\
\text { understand } \\
\text { the } \\
\text { material }\end{array}$ \\
\hline RIM2C & $\sqrt{ }$ & & & $\checkmark$ \\
\hline OPM2C & & $\checkmark$ & V & \\
\hline VEL2C & $\sqrt{ }$ & & & $\checkmark$ \\
\hline HM2C & & $\sqrt{ }$ & $\checkmark$ & \\
\hline $\mathrm{AH} 2 \mathrm{C}$ & $\sqrt{ }$ & & & V \\
\hline IRA2C & & $\checkmark$ & V & \\
\hline NQA2C & $\sqrt{ }$ & & & V \\
\hline RIS2 & & $\checkmark$ & $\sqrt{ }$ & \\
\hline MZLS2 & $\sqrt{ }$ & & & $\sqrt{ }$ \\
\hline ESPSI & & $\sqrt{ }$ & V & \\
\hline FKPSI & $\sqrt{ }$ & & & V \\
\hline AN2D & & $\sqrt{ }$ & V & \\
\hline KHPSI & 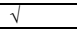 & & & V \\
\hline PT2D & & $\sqrt{ }$ & $\sqrt{ }$ & \\
\hline NFEF & $\sqrt{ }$ & & & v \\
\hline PBED & & $\sqrt{ }$ & $\sqrt{ }$ & \\
\hline MR2D & $\sqrt{ }$ & & & J \\
\hline AZ2D & & $\sqrt{ }$ & $\sqrt{ }$ & \\
\hline HT2DA & V & & & V \\
\hline IC2D & & $\checkmark$ & $\sqrt{ }$ & \\
\hline $2 \mathrm{~N} 2 \mathrm{P}$ & $\sqrt{ }$ & & & 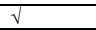 \\
\hline EF2DC & & $\sqrt{ }$ & $\sqrt{ }$ & \\
\hline SAC2D & $\sqrt{ }$ & & & $\checkmark$ \\
\hline RR2S & & $\sqrt{ }$ & $\sqrt{ }$ & \\
\hline ANS2 & $\sqrt{ }$ & & & $\sqrt{ }$ \\
\hline NAPSI & & $\checkmark$ & $\checkmark$ & \\
\hline
\end{tabular}

Research findings (1) virtual face-to-face does replace teachers / lecturers in teaching, but it is not optimal as face-to-face. The problem in understanding the material was that some of the participants said that they could be searched via Google or ask friends, but even though the learning target was reached, the percentage was still not able to represent it at face-to-face, meaning that it was often misunderstood as participant expressions.

Tabel 2. Participant's Psychological Expressions

\begin{tabular}{|c|c|c|c|c|c|}
\hline $\begin{array}{l}\text { Participant } \\
\text { ID }\end{array}$ & SBS & TMTC & MPS & SM & NP2N \\
\hline RIM2C & v & $\sqrt{ }$ & $\sqrt{ }$ & $\sqrt{ }$ & $\sqrt{ }$ \\
\hline OPM2C & J & $\sqrt{ }$ & $\sqrt{ }$ & & \\
\hline VEL2C & j & & $\sqrt{ }$ & $\checkmark$ & $\sqrt{ }$ \\
\hline HM2C & V & v & $\sqrt{ }$ & & \\
\hline $\mathrm{AH} 2 \mathrm{C}$ & $\sqrt{1}$ & & $\sqrt{ }$ & $\sqrt{ }$ & $\sqrt{ }$ \\
\hline IRA2C & V & $\sqrt{ }$ & $\sqrt{ }$ & & \\
\hline NQA2C & v & & $\sqrt{ }$ & $\sqrt{ }$ & $\sqrt{ }$ \\
\hline RIS2 & V & $\sqrt{ }$ & $\sqrt{ }$ & & \\
\hline MZLS2 & $\sqrt{1}$ & & $\sqrt{ }$ & $\sqrt{ }$ & $\sqrt{ }$ \\
\hline ESPSI & $\sqrt{1}$ & $\sqrt{ }$ & $\sqrt{ }$ & & \\
\hline FKPSI & $\sqrt{ }$ & & $\sqrt{ }$ & $\sqrt{ }$ & $\sqrt{ }$ \\
\hline AN2D & $\sqrt{ }$ & $\sqrt{ }$ & $\sqrt{ }$ & & \\
\hline KHPSI & $\sqrt{ }$ & & $\sqrt{ }$ & $\sqrt{ }$ & $\sqrt{ }$ \\
\hline PT2D & $\sqrt{ }$ & $\sqrt{ }$ & $\sqrt{ }$ & & \\
\hline NFEF & V & & $\sqrt{ }$ & V & $\sqrt{ }$ \\
\hline PBED & $\sqrt{ }$ & $\sqrt{ }$ & $\sqrt{ }$ & & \\
\hline MR2D & J & & $\sqrt{ }$ & $\sqrt{ }$ & $\sqrt{ }$ \\
\hline AZ2D & $\sqrt{1}$ & $\sqrt{ }$ & $\sqrt{ }$ & & \\
\hline HT2DA & $\sqrt{ }$ & & $\sqrt{ }$ & $\checkmark$ & $\sqrt{ }$ \\
\hline IC2D & J & $\sqrt{ }$ & $\sqrt{ }$ & & \\
\hline $2 \mathrm{~N} 2 \mathrm{P}$ & $\sqrt{ }$ & & $\sqrt{ }$ & $\checkmark$ & $\sqrt{ }$ \\
\hline EF2DC & V & $\sqrt{ }$ & $\sqrt{ }$ & & \\
\hline SAC2D & $\sqrt{2}$ & & $\sqrt{ }$ & V & $\sqrt{ }$ \\
\hline RR2S & J & $\sqrt{ }$ & $\sqrt{ }$ & & \\
\hline ANS2 & $\sqrt{1}$ & & $\sqrt{ }$ & V & $\sqrt{ }$ \\
\hline NAPSI & $\sqrt{ }$ & $\sqrt{ }$ & $\sqrt{ }$ & $\sqrt{ }$ & $\sqrt{ }$ \\
\hline
\end{tabular}

\section{DISCUSSION AND CONCLUSION}

Psychological disturbances occur when learning worship from face-to-face to online, as research in Jordan has obtained the data will be useful for the relationship between e-learning models and psychosomatic disorders as a basis for identifying students' emotional and psychological needs and proposing practical solutions for their educational well-being. appears in the health sector, namely treatment that strengthens lung function and lung immunity, although it still needs trials [21] but in the world of education, online learning continues and quickly a teacher needs to make a breakthrough so that learning materials and objectives can be achieved to learners.

As in Tables 1 and 2, even though they feel heavy and fulfilled because there are more on-line assignments, many of the materials cannot be understood, but they are creative to solve all problems on campus assignments by being able to organize themselves. This indicates that the participant cares about mental health and the quality of motivation to learn [9]. However, there are more recommendations for health workers in dealing with COVID 19 patients because the number of patients is very global, almost evenly distributed in all regions. Including patients with certain diseases [22] of course it needs special attention. This means that even through online lectures, it is necessary to convey a message of truth about health information and if there are people who already have a history of triggering health problems, they should also be able to provide assistance and remind each other the importance of maintaining health.

The new pattern that emerged was that students felt the importance of the teacher more than just being physically present, the awareness that with the pandemic event it turned out that they had a new life at home in mind in the behavior experienced by almost all of the participants. And this can be called a new normal. The problem is whether the new normal lasts temporarily or forever.

\section{REFERENCES}

[1] E. Di Lorenzo and M. Sibillo, "Economic Paradigms and Corporate Culture after the Great COVID-19 Pandemic: Towards a New Role of Welfare Organisations and Insurers," Sustainability, vol. 12, no. xx, pp. 1-14, 2020.

[2] K. S. Sauer, S. M. Jungmann, and M. Witthöft, "Emotional and Behavioral Consequences of the COVID-19 Pandemic: The Role of Health Anxiety , Intolerance of Uncertainty , and Distress ( In ) Tolerance," Int. J. Environ. Res. Public Heal., vol. 17, no. xx, pp. 1-18, 2020.

[3] W. Taylor et al., "A Review of the State of the 
Art in Non-Contact Sensing for COVID-19," Sensors, vol. xx, no. xx, pp. 1-19, 2020.

[4] E. Yamamura and Y. Tsutsui, "The Impact of Postponing 2020 Tokyo Olympics on the Happiness of O-MO-TE-NA-SHI Workers in Tourism: A Consequence of COVID-19," Sustainability, vol. 12, no. 19, pp. 1-16, 2021.

[5] D. Levy, Teaching efectively with zoom. Cambridge, 2020.

[6] C. S. Gonz and A. Infante-moro, "Implementation of E-Proctoring in Online Teaching : A Study about Motivational Factors," Sustainability, vol. 12, no. 8, pp. 1-13, 2020.

[7] L. Zhang, K. Chen, H. Jiang, and J. Zhao, "How the Health Rumor Misleads People's Perception in a Public Health Emergency: Lessons from a Purchase Craze during the COVID-19 Outbreak in China," Int. J. Environ. Res. Public Heal., vol. 17, no. xx, p. 15, 2020.

[8] H. Mostafa, "Examining the Relationship Between Motivations and Resilience in Different International Student Groups Attending U . S . Universities," J. Int. Students, vol. 10, no. 2, pp. 306-319, 2020.

[9] R. Jindori, Y. Vakkai, K. S. Chaplin, and J. J. Crabbe, "Sociocultural Factors That Impact the Health Status, Quality of Life, and Academic Achievement of International Graduate Students : A Literature Review," J. Int. Students, vol. 10, no. 3, pp. 758-775, 2020.

[10] T. Gao and V. Erokhin, "Capturing a Complexity of Nutritional , Environmental, and Economic Impacts on Selected Health Parameters in the Russian High North," Sustainability, vol. 12, no. 2151, pp. 1-25, 2020.

[11] A. Priyono and A. Moin, "Identifying Digital Transformation Paths in the Business Model of SMEs during the COVID-19 Pandemic," J. Open Innov. Technol. Mark. Complex, vol. 6, no. 104, pp. 1-22, 2020.

[12] H. Chen and E. Hasler, "How Do Chinese International Students View Seeking Mental Health Services ?," J. Int. Students, vol. 10, no. 2, pp. 286-305, 2020.

[13] T. Choi, "Sustainability agglomeration effect of skill-based local labor pooling: evidence of
South Korea," Sustainability, vol. 12, no. 8, pp. $1-15,2020$.

[14] E. Dooley, "An ethnographic look into farmer discussion groups through the Lens of social learning theory," Sustainability, vol. 12 , no. 18 , pp. 1-21, 2020.

[15] S. Zafar et al., "COVID-19: Current Developments and Further Opportunities in Drug Delivery and Therapeutics," Pharmaceutics, vol. 12, no. xx, pp. 1-26, 2020.

[16] K. Pogue et al., "Influences on Attitudes Regarding Potential COVID - 19 Vaccination in the United States," Vaccines, vol. 8, no. xx, pp. 1-14, 2020.

[17] Y. J. Sang Heui Seo, "Cold-Adapted Live Attenuated SARS-Cov-2 Vaccine Completely Protects Human ACE2 Transgenic Mice from SARS-Cov-2 Infection," Vaccines, vol. 2, no. xx, pp. 1-17, 2020.

[18] M. G. and Y. G. S. Muhammad Umar, Zulqurnain Sabir, Muhammad Asif Zahoor Raja , Muhammad Shoaib, "A Stochastic Intelligent Computing withNeuro-Evolution Heuristics for Nonlinear SITRSystem of Novel COVID-19 Dynamics," Symmetry (Basel)., vol. 12, no. xx, pp. 1-17, 2020.

[19] S. Xu, Y. Lu, T. Zhang, H. Xiong, and W. Wang, "Cross-Sectional Seroepidemiologic Study of Coronavirus Disease 2019 ( COVID-19) among Close Contacts, Children, and Migrant Workers in Shanghai," Int. J. Environ. Res. Public Heal., vol. 17, no. xx, pp. 1-10, 2020.

[20] A. Mattila, R. M. Martin, and E. D. Deiuliis, "Education sciences Simulated Fieldwork: A Virtual Approach to Clinical Education," Educ. Sci, vol. 10, no. xx, pp. 1-14, 2020.

[21] R. Hage, C. Steinack, F. Gautschi, and M. M. Schuurmans, "Transplant Drugs against SARS , MERS and COVID-19," Transplantology, vol. 1, no. xx, pp. 71-84, 2020.

[22] S. Czajkowska, J. Rupa-matysek, L. Gil, and A. Surdacka, "Practical Recommendations for Treatment of Dental Patients with Congenital Bleeding Disorders during the Covid-19 Pandemic : A Narrative Review," Int. J. Environ. Res. Public Heal., vol. 12, no. xx, pp. 1-16, 2020. 